\title{
CONTEXTUAL CONTENTS OF FRIDAY SERMONS IN THE RELIGIOUS MODERATION DISCOURSE IN JAYAPURA CITY
}

\author{
Syarifuddin ${ }^{1}$, Asnandar Abubakar' ${ }^{2}$, Hamsiati ${ }^{3}$, Wardiah Hamid ${ }^{4}$ \\ 1,2,3,4 Office of Religious Research and Development Makassar, Ministry of Religious Affairs \\ ${ }^{1}$ syarifuddinamir84@yahoo.com, 2asnandar2.aja@gmail.com, 3hamsiatib@gmail.com, \\ ${ }^{4}$ hamidwardiah722@gmail.com
}

\begin{abstract}
This study describes the contents of the Friday sermon selected by the preachers in Jayapura City. The research method used is a qualitative method by recording Friday sermons from several types of mosques, that is the Great Mosque of Ash Shalihin in Jayapura City, Baiturrahim Mosque, Kotaraja, Skyland Complex, and the Campus Mosque of State Islamic Institute (IAIN) Fathul Muluk in Jayapura. This study found that the procedure for selecting khatibs in Jayapura City was coordinated by the Ministry of Religious Affairs except for Heram and Muara Tami Districts. Therefore, content easier to coordinate. In general, the preachers in Jayapura City prefer themes around matters of faith, jurisprudence, and morals. Besides that, the preachers also often choose content related to events that are currently viral. Meanwhile, there is very little content related to religious moderation, including local wisdom. Several factors are the religious context in Jayapura, which is predominantly Christian so that the preacher tends to choose a theme that is safe from controversy. Also, literacy about religious moderation material as well as local wisdom possessed by preachers and the community is still lacking.
\end{abstract}

Keywords: Friday sermon; religious moderation; local wisdom; mosques.

Abstrak: Penelitian ini mendeskripsikan konten-konten khutbah Jumat yang dipilih oleh khatib di Kota Jayapura. Metode penelitian yang digunakan yaitu metode kualitatif dengan merekam khutbah jumat dari beberapa tipe masjid, yakni Masjid Agung Ash Shalihin Kota Jayapura, Masjid Baiturrahim Kotaraja Kompleks Skyland, dan Masjid Kampus IAIN Fathul Muluku Jayapura. Penelitian ini menemukan bahwa prosedur pemilihan khatib di Kota Jayapura dikoordinasikan oleh Kantor Kementerian Agama kecuali Distrik Heram dan Muara Tami. Oleh karena itu, konten lebih mudah dikordinasikan. Secara umum, khatib di Kota Jayapura lebih memilih tema-tema seputar persoalan akidah, fikih maupun akhlak. Disamping itu, khatib juga sering memilih konten berkaitan peristiwa-peristiwa yang sedang viral. Sementara, konten yang berkaitan dengan moderasi beragama termasuk halnya kearifan lokal masih sangat minim. Beberapa faktor yaitu konteks keagamaan di Jayapura yang mayoritas beragama Kristen sehingga khatib cenderung memilih tema yang aman dari kontroversi. Disamping itu, literasi para khatib dan masyarakat yang masih kurang terhadap materi moderasi beragama serta kearifan lokal.

Kata Kunci: Khutbah jumat; moderasi beragama; kearifan lokal; masjid.

\section{A. Introduction}

Khutbah Jum'at is a medium for transferring knowledge to society. The level of public understanding is sometimes influenced by lecture materials from lecturers in an area. Therefore, the role of the preacher as one of the da'wah instruments is very important. Among the things 
that affect the sermon material of a $d a^{\prime} i$ are the educational background, organization, and social conditions of the community.

Historically, sermons or lectures during the time of the Prophet were delivered privately by the Messenger of Allah as the sole authority for teaching Muslims. At this time, the scholars took legal istinbath regarding the procedures for carrying out Friday prayers which included harmonious, sunnah and so on. From any material perspective, what was conveyed by the Prophet was quite diverse from various aspects of Islamic teachings. So that the Friday sermon really reflects the teaching media of the Islamic Religion Rahmatan lil Alamin. This tradition was then continued by Khulafaur Rasyidin after the Prophet Muhammad died.

Friday sermons as a medium for conveying Islamic teachings then became one of the provocative media and propaganda for the interests of the authorities. A preacher in delivering his sermon, must praise the strengths of the government. so it is not uncommon for khutbah jum'at as a medium to attack the opposition. Therefore, at the time of the Caliph Umar bin Abdul Aziz who was known as a just leader, he tried to break this bad tradition by replacing the message of doing justice. He prohibited the preacher from blaspheming Ali's followers and other opposition groups. He also required the preachers to convey the message of the Koran as stated in Surah al-Nahl verse: 90. Umar bin Abdul Aziz considered this tradition to be an act of wrongdoing and therefore it had to be cut and replaced with a better tradition ${ }^{1}$. Until finally the tradition of reciting Surah al-Nahl verse 90 in the sermon above is still valid in various Islamic societies, including in Indonesia.

In the context of Indonesia as a multicultural country with various religions, cultures and cultures, and rich in religious organizations that have different religious practices, some are inclusive that can accept the existence of other groups, some are exclusive that cannot accept other groups in other words. they used to label a different group from them. These religious groups usually propagate their teachings through the media of studies, lectures, even to Friday sermons which are considered by jurists to be sacred moments that also determine the validity of Friday prayers. So it is not uncommon for hate speech against certain groups to be sung in Friday sermons.

The moment of the reform era was used by hardline groups (radicals) in Islam to reproduce their teachings. In general, this group reports back to realize the idea of an Islamic state and to question the validity of Pancasila as the basis of the Unitary State of the Republic of Indonesia. The freedom that was restrained during the New Order period is like a heavenly wind that must be made good use of. These radical groups usually attack other groups who do not understand physically and verbally through the media, studies, even through lectures and Friday sermons. A 2010 research result of the CSR of UIN Syarif Hidayatullah Jakarta entitled The Seeds of Radical Islam in Mosques: Case Studies in Jakarta and Solo, shows a symptom that mosques and musalla are the places of propaganda for the Islamic state 2 .

Until then, there was a shift in religious understanding in society. Muslims in Indonesia who used to be more familiar with organizations such as NU, Muhammadiyah, Persis, DDI, Nahdatul Wathan and so on. Schools like Salafy Wahabi, which tend to be puritanical, exert a stronger influence. They usually attack the religious traditions of the community that are deemed contrary to pure Islamic teachings. Religious groups such as Hizbut Tahrir, which fight for the establishment of the Khilafah state and consider another system of government such as that adopted by the Unitary Republic of Indonesia is the Thagut system. As previously mentioned, they usually propagate their teachings through preaching media such as religious studies, lectures or Friday sermons ${ }^{3}$.

\footnotetext{
${ }^{1}$ A Syalabi, Sejarah Dan Kebudayaan Islam, II. (Al Husna Zikra, 2000).

2 B. dan A. M. M Singh, Jejaring Radikalisme Islam Di Indonesia (Kencana, 2012).

${ }^{3}$ Syamsurijal, Pergeseran Paham Keagamaan Mahasiswa Islam Di Kawasan Timur Indonesia, 2015.
} 
Several studies have factually succeeded in showing the sterility of the mosque from the issue of intolerant sermons 5 6. In fact, there are clearly many preachers who always call for the importance of tolerance?

The discourse on khatib certification in the end experienced a lot of opposition from Muslims because it was considered an excessive fear of the government towards Muslims and could justify the apparatus' regressive attitude towards preachers/preachers who were opposed to the government. Regardless of the controversy, it is a fact that this discourse arose because of unrest that the Friday sermon was used by some groups to incite hatred against other groups. Besides, there are also many preachers who lack competence so they often ignore the terms and harmonious sermons, including many preachers who are not fluent in reciting verses of the Koran.

This study was conducted in Jayapura City as a very multi-participant city consisting of various ethnicities and religions. The choice of locus is very important, especially if it is directed to explore potential messages of moderation, peace, tolerance (intolerance) or local issues that develop in society in Friday sermons. The study can assist the Ministry of Religion in determining development strategies in the field of religion in realizing a harmonious and peaceful religious life in Jayapura City.

There are several objectives to be achieved in this research, namely: describing the form of Friday sermons in Jayapura city and revealing what topics are contained in the Friday sermon text in urban mosques which are the research targets. The benefits expected from the research results are: first, practically it is expected to provide information on the topics contained in the sermon material at mosques in Jayapura City. Second, this research is expected to become a reference for formulating policies related to the implementation of Friday sermons.

\section{B. Theoretical Review}

The main theory used in this research is qualitative content analysis theory. Historically, qualitative content analysis is the antithesis of quantitative content analysis methods that are only oriented to quantitative numbers. Kracauer criticizes the quantitative orientation for being seen as ignoring certain qualities in the text. According to him, the pattern or integrity of a text must be demonstrated not by counting and measuring the visible content but showing various possible interpretations ${ }^{8}$.

Alhaide as quoted by Kriyantono in ${ }^{9}$, that qualitative content analysis is also known as Ethnographic Content Analysis (ECA), which is a combination of objective analysis with participant observation. That is, content materials are analyzed with a combination of in-depth interviews or documentation so that ${ }^{10}$, specific statements can be put in the right context. Furthermore, it was explained that content analysis must pay attention to: (1) Content or content about the social situation surrounding the document (text) to be studied, (2) The process of a media product or message being actually created, (3) Emergency, namely the gradual formation from the meaning of a message through understanding and interpretation ${ }^{11}$.

\footnotetext{
${ }^{4}$ T Kurniawati, "Naskah Khutbah Karya Uci Sanusi; Sebuah Edisi Teks Dan Kajian Topik,” Jurnal Jaladri 3, no. 1 (2017): 43-50.

${ }^{5}$ H Khatmi, Tata Cara Khutbah Dan Kompetensi Khatib Jum'at Di Palangkaraya (Insitut Agama Islam Negeri Palangkaraya, 2016).

${ }^{6}$ R Abdillah, Pesan Dakwah Khatib Jum'at (Studi Kualitatif Di Masjid Nurul Fattah Jl. Demak Kecamatan Krembangan Surabaya Edisi Mei 2014 Minggu Ke-5 Oleh Ust. Umar Haqqi AR)., 2015.

7 Ali Masyhar and F. S Harmoko, "Peran Khutbah Jum'at Dalam Mengantisipasi Radikalisme Beragama," Jurnal Pengabdian Hukum Indonesia 2, no. 5 (2019): 178-183.

${ }^{8}$ E. al. Titscher, Stefan, Methods of Text and Discourse Analysis. Metode Analisis Teks Dan Wacana (Pustaka, 2009).

${ }^{9}$ I. S. W Wibowo, Aplikasi Praktis Bagi Penelitian Dan Skripsi Komunikasi (Mitra Wacana Media, 2013).

${ }^{10}$ Titscher, Stefan, Methods of Text and Discourse Analysis. Metode Analisis Teks Dan Wacana.

${ }^{11}$ Wibowo, Aplikasi Praktis Bagi Penelitian Dan Skripsi Komunikasi.
} 
The categorization of content or content in the sermon is based on the main teachings of Islam covering aspects of scientific studies known in Islamic studies. These aspects as mentioned by (Nasution) ${ }^{12}$ consist of theology, worship, morals, mysticism, philosophy, history, culture, politics and so on. While a simpler categorization is quoted from the opinion of al-Maraghi in the interpretation regarding the main contents of the Surah Al-Fatihah, it is called the ummul qur'an, namely because Surah al-Fatihah summarizes the contents of the al-Quran which is the main source of Islamic teachings which includes aspects: Tauhid (Akidah), Worship, the way to get happiness, the promises and threats of Allah and lessons on the stories of the previous people.

One thing that needs to be seen in examining the content of the sermon is that it is fully harmonious. According to the opinion of the Syafii School, there are five pillars of Friday sermons, namely: praising Allah swt., Salawat to the Messenger of Allah (peace be upon him), the message of devotion (the three pillars must be in both khutbahs), reading the verse in one of the two sermons and praying to your people 'minin in the second sermon ${ }^{13}$. Meanwhile, the opinion of the Hambali school does not include prayers to the Mu'minin people in the second sermon as a pillar of the sermon ${ }^{14}$.

\section{Religious Moderation}

Starting from the white paper on Religious Moderation launched by the Ministry of Religion at the end of 2019 which states that moderation is a shared commitment to maintaining a complete balance, where every member of society, regardless of ethnicity, culture, religion, and political choices must be willing to listen to each other each other, and learn from each other to practice the ability to manage and overcome differences between them. So it is clear that religious moderation is closely related to maintaining togetherness by having a tolerant attitude, an ancestral heritage that teaches us to understand each other and share feelings for one another who is different from us. The indicators of religious moderation are: 1) commitment to nationality; 2) tolerance; 3) nonviolence; and 4) accommodating to local culture. These four indicators can be used to identify how strong religious moderation is being practiced ${ }^{15}$.

A more detailed explanation is given regarding religious moderation according to the Koran in terms of various aspects such as divinity (aqidah), law (Sharia), aspects of social life, economic aspects. Political aspects, social relations aspects and so on. It's just that, here will explain how the attitude of religious moderation according to the Koran in the aspect of social relations with its relation to inter-religious relations, including inter-sectarian relations (mazhab). According to him, wasathiyah emphasizes differences in various aspects of life, therefore it is emphasized that there is an attitude of mutual forgiveness, can live side by side to help each other to complement each other ${ }^{16}$. The fact that in society there are various religions and beliefs, it is forbidden to insult the practices of other religions even though from the perspective of belief it is considered bad. There are two things that need to be considered in the relationship between religious communities; 1) giving opportunities to anyone to carry out their worship including working with them 2) there needs to be an attitude of tolerance as in God's word in (Saba: 25-27). He further explained that the main principle of religious moderation in Islam is to be fair even to groups that are not liked ${ }^{17}$.

\footnotetext{
${ }^{12}$ H Nasution, Islam Ditanjau Dari Berbagai Aspeknya, I. (Universitas Indonesia Press, 1985).

${ }^{13}$ W Al-Zuhaili, Al-Fiqh Al-Islami Wa Adillatuh, Jilid II., 1985.

${ }^{14}$ Ibid.

${ }^{15}$ RI Kementerian Agama, Moderasi Beragama, 2019, Kementerian Agama RI.

${ }^{16}$ M. Quraish Shihab, Wasathiyyah: Wawasan Islam Tentang Moderasi Beragama (Tangerang: Lentera Hati, 2019).

${ }^{17}$ Ibid.
} 


\section{Methods}

This research will be conducted in Jayapura City. The time for collecting research data was divided into two phases, namely: firstly, the initial data collection, and secondly, the second phase of field data collection. This research uses a descriptive qualitative approach that will be combined with descriptive content analysis. The content analysis in this study was carried out by collecting several recordings of Friday sermons in several mosques with reference to the typology of Regional Mosques (Grand Mosque), campus mosques, residential mosques and mosques in the general public (non-residential). The recorded sermon is then transcribed and the title, theme or message is presented as part of the content analysis.

Data collection was carried out by interview, observation, and documentation. Interviews were also conducted specifically with the preacher to find out the religious understanding, educational background, affiliation of the khatib Friday religious organization and the reference (reading) of the khatib. Tracing this data is very important considering that these elements often influence the preaching pattern of a preacher. . Field observations were also carried out to observe the process of implementing Friday sermons directly. Documentation techniques through audio or video recording, and information search in the form of related documents were also carried out to find out the socio-religious culture of Jayapura City as a research location, including those related to mosque management policies, categorization, and sermon schedules.

\section{Result and Discussion}

\section{Friday Sermons and Mosque Management Policies in the City of Jayapura}

Islam is the second most widely practiced religion in Jayapura City. Meanwhile, Christianity, which is the majority religion, is also considered the majority religion as well as a representation of local tribes. Islam is generally adhered to by immigrant communities from Sulawesi, Java, Maluku and so on. They travel to Papua for various reasons, generally with the motive of seeking a better economic livelihood from their hometowns. As a result, there was competition between the local population and the immigrant population who were predominantly Muslim. This competition also often spills over into religious issues.

There is a kind of concern for some local residents who are Christian seeing the growth of Muslims in Papua, especially Jayapura City, including the proliferation of mosques and prayer rooms. As a result, the potential for competition that could lead to conflicts between religions is quite open. In the course of time, several conflicts have occurred in Papua such as the Tolikara Incident and the Jafar Umar Talib Case in Muara Tami. This incident has also become a warning for all parties in Papua, especially in the City of Jayapura, to always maintain the harmony of religious harmony ${ }^{18}$.

In its implementation, every year the Ministry of Religion of the City of Jayapura, under the coordination of the Islamic Religious Instructor, writes to every mosque in Jayapura City to include a schedule for Khatib and Tarwih lectures in the month of Ramadan. The Ministry of Religion then verifies and regulates if there is a simultaneous schedule between a preacher at 2 mosques. If a mosque does not have a candidate for a preacher, then the ministry of religion then arranges and determines the schedule. In the end, the Ministry of Religion made a schedule of Friday sermons for 1 year to be used as a guide for each mosque. On the same side, the Ministry of Religion of Jayapura City has data on 822 preachers / lecturers who take turns filling the pulpit for sermons and Ramadan lectures in Jayapura City.

To make it easier for the preacher or speaker to choose a topic for discussion, the ministry of religion also provides examples so that the themes are not repeated in a mosque. These themes are usually contextual in nature, for example during the month of Ramadan, the themes discussed are related to fasting and zakat. In addition, there are several themes related to

\footnotetext{
${ }^{18}$ Ridwan, Insiden Tolikara Dan Jafar Umar Thalib: Kontroversi Mushalla Yang Dibakar Dan Drama Jihad Di Papua (Kementerian Agama Provinsi Papua, 2017).
} 
moderation, such as: Prohibition of Swearing, Blasphemy and Sowing Hatred, Prohibition of Provoking and Pitting Sheep to Peoples, The Importance of Strengthening Islamic Ukhuwah, Maintaining Harmony in National and Community Life, and Beautiful Unity and Togetherness in Responding to Differences .

With this regulatory system, the Ministry of Religion is able to minimize the potential for sermons or lectures that can trigger disharmony in religious life and between religious communities. This step was also taken by the Ministry of Religion, because at certain times, the Intelligence and the police sometimes asked for sermons from several mosques, especially during the holy day. Ustadz Burhanuddin said: "I am probably the busiest person on Hari Raya because in addition to preparing for the takbiran, Id prayers and so on, I also have to deposit every preacher praying in Jayapura City because he was asked by intelligence. So we have to be busy here and there calling mosque administrators who have not entered the data of their preacher."

The scheduling system implemented by the Jayapura City Ministry of Religion as above only applies to the Jaypura Utara, South Jayapura and Abepura Disciplines. Meanwhile, in Heram and Muara Tami districts, scheduling was carried out by an institution established by the community in the district, namely the Musalla Mosque Coordinating Board (BKMM). This institution is not only engaged in the issue of mosques according to their name, but furthermore they are also active in various social activities, such as preparing burial places for Muslims, celebrating Islamic holidays that directly involve the community, and so on.

Eko Siswanto as the Chairperson of the Heram District BKMM who is also the Dean of the Sharia Faculty of IAIN Fathul Muluk, said that the organization he leads, the main objective is to manage mosque activities including determining the schedule of the preacher at each mosque. In preparing the Khatib's schedule, they mostly used human resources from the IAIN Fathul Muluk Campus. The reason is to avoid polemics in the community regarding the materials presented. The lecturers at IAIN Fathul Muluk campus are considered to be more moderate and understand the needs of the community. However, the BKMM also took a lot of $d a^{\prime} i$ from outside the campus.

To avoid polemic in the community, the BKMM always warns the preachers to pay attention to the duration of the sermon. What is no less important that the preacher needs to pay attention to is not to unequivocally address the khilafiyah problem, namely by blaming an opinion that is believed by a community religious group. BKMM often emphasizes to mosque administrators that in managing mosques, they should not overly show organizational groups because they have the potential to create groups in a mosque.

In this regard, Eko Siswanto recounted that once a preacher questioned the use of a stick during the Friday sermon procession, as a result the congregation became antipasti. For this reason, BKMM always provides control over the preachers if there are reports from congregations regarding controversy over the material of sermons or lectures. "Some of our speakers are from various professions who are pure lecturers, there are also teachers, there are also entrepreneurs. We use a lot of academic lecturers at IAIN because most of the lecturers live in Heram. "

\section{Content Analysis of Friday Sermons}

Several sermon themes that were delivered in Jayapura City, were recorded on several processions of Friday Khutbahs in several mosques. Several mosques in Jayapura were recorded, as follows: (1) Great Mosque of Ash-Shalihin, Jayapura City, Khatib Friday, Sukri Nawir (Lecturer at IAIN Al-Muluk Jayapura), with the theme "Haram Months". (2) Baiturrahim Kotaraja Mosque in the Skyland Complex, Khatib H. Abd. Jalil (Imam of the Baiturrahim Kotaraja Mosque) with the theme "Facilitating Other People's Affairs". (3) Al-Hikmah Mosque Tanah Hitam Kotaraja Abepura, Khatib Suddin Lasahiya (Mosque of Islamic Religion Teachers / Management) with the theme "Istiqamah on the Way of Truth". (4) The Great Mosque of Ash-Shalihin, Jayapura City, Khatib Friday, Muh. Taslim (Lecturer at IAIN Al-Muluk Jayapura), with the theme "Self-Introspection and Having a SelfStudy". (5) Baiturrahim Kotaraja Mosque in the Skyland Complex, Khatib Muhammad Sahudi (IAIN 
Al-Mulk Lecturer, IAIN Al-Muluk Jayapura) with the theme "Sorry to Give". (6) IAIN Al-Muluk Khatib Sudirman Campus Mosque (IAIN Al-Muluk Jayapura Lecturer) with the theme "Islamic Lifestyle".

\section{Pillars of Sermons}

Broadly speaking, the preachers understand the pillars of Friday sermons. This can be seen from the text of the sermon which is delivered without missing a single pillar of the Friday sermon which determines the validity of the sermon, starting from saying the sentence of tahmid, salawat, reading verses of the Koran, taqwa wills and ending with prayers for all Muslims. Even though in practice, the preacher is harmonious with an almost uniform editorial. For example, in saying tahmid sentences generally start with the sentence الحمد لله , likewise in saying salawat to the Prophet Muhammad, starting with the sentence اللهم صل whe salawat is then perfected in the second sermon by first reading Surah Al-Ahzab, which explains the commandment to pray to the Prophet Muhammad.

The next pillar which relates to the text of the sermon is to have the intention of being taqwa to Allah. In his delivery, the preacher used the editor أوصيكم و إياب بتقوى الله even though some of them only used the editor اتقوا الله In the perspective of the Syafii School, the editorial team is considered sufficient as a will to pious.

\section{Sermon Material}

Generally, the preachers in Jayapura, in delivering Friday sermons, did not include the title of the jum'at khutbah which was the subject of the discussion. They usually start with an opening which includes opening the sermon by remembering tahmid, two sentences of shahada, salawat, wasiat taqwa, reading verses of the Koran in Arabic. After that, the opening text is followed by an invitation to praise Allah and give alms to the Prophet Muhammad in Indonesian.

As previously stated, the preacher then delivered the Friday material without mentioning the detailed title. Therefore, the audience directly cannot grasp the subject except by listening to the whole or a large part of the sermon text.

From a communication perspective, the inclusion of the title is considered very important to attract the attention of the audience regarding the subject of the sermon. besides that, the title can describe the outline of the content of the sermon so that the audience is easier to accept and understand.

The content of the sermon is generally conveyed coherently and in accordance with the subject matter. The discussion does not extend to material that is not directly related to the subject matter so that the preacher can take advantage of the time duration in explaining the content of the sermon efficiently. The time used is approximately 15 minutes. This is very important to avoid audience saturation which can cause drowsiness so that the audience falls asleep and does not listen to the sermon material.

For example, the text of the sermon delivered by Ustadz Abd. Jalil. Although in his presentation he did not mention the title of the sermon, he coherently explained the message related to the suggestion "Make it easier for other people's affairs." In a structured manner, he motivated the congregation to always simplify the affairs of other people in the world so that later Allah swt will retaliate by making things easier in the hereafter. He also strengthened the message by quoting the Qur'anic Verses and the hadith of the Prophet. The following is an example of delivering text by Ust. Abd Jalil:

This hadith provides motivation and encourages people, it is recommended to help one another one another, it is recommended to care for each other's sincerity. This suggestion is a reward promised by Allah. One difficulty that we solve for our brothers, the guarantee given by Allah Almighty, is to clear the difficulties in the hereafter. Why give in the hereafter because in the world difficulties can be resolved with various help from each other but difficulties in the hereafter cannot be helped by others, someone is weak to difficulties. But Allah guarantees that when we want 
to help with our brother's difficulties, Allah will guarantee that our difficulties will be resolved later in the hereafter.

The text of the sermon above gives a message to the congregation to always help each other because this behavior is a cause for Allah to provide help on the Day of Judgment. Khatib further emphasized that the human condition on the Day of Resurrection is very difficult. Therefore, it is only with God's help that humans can get out of these difficulties and that can be obtained by helping fellow humans. At the end, the preacher also said that if a human being makes it difficult, wrongdoing and tortures another human then in return, Allah will also torture him on the Day of Judgment.

Ustadz Sukri Nawir in delivering his sermon material, he also did not include the title of the sermon. However, with a light delivery and with an interesting intonation and rhetoric, the sermon material is quite easy to digest. He conveyed a message regarding what to do in the Haram months. Previously, he delivered by quoting the Koran Surah Al-Taubah: 36, at the beginning of the sermon. He then mentioned the haram months, namely the Month of Zulqadah, Month of Zulhijjah, Month of Muharram and Month of Rajab. The main message that was then conveyed was that the Jamaah should always do good and leave immorality, especially in the haram months which is evidence of devotion to Allah SWT.

The numbers determined by Allah are 12 months, of which four are haram. When we listen to the haram months. When we listen to haram places it means that there are places where we are prohibited from committing immorality. We know that Makkah al-Mukarrah is a haram place, we know that Medina Al-Munawwarah is a haram place and some of the Al-Aqsa Mosque is a haram place. We must be careful not to carry out disobedience to do good. When we return to the haram month of amak, there are orders that we must do in the haram month. The four months of haram were described by the Holy Prophet Muhammad. Tasalatu mutawalia. Month of Zulqada, Month of Zulhijjah, Month of Muharram. Today we enter the month of Zulqada. One more month of Rajab that we have passed. What are the consequences when we enter the haram month? This haram month, the month of Zulqadah is the month of Hajj. Whoever intends to have Hajj is granted the Hajj, that is the first.

From several recorded sermon manuscripts, it proves that the preacher in Jayapura city tends to be normative in choosing a theme by choosing the theme of good and bad morals, issues of worship and so on. They are somewhat reluctant to choose social themes given the condition of Jayapura Muslims who are a minority of Christianity. There is a concern that social themes can cause offense with other religions. Besides that, the $d a^{\prime}$ is are somewhat reluctant to choose a theme related to social relations between religious communities because of concerns about misinterpretation in theology related to that theme. For example, the preachers were worried about quoting Dalí's explanation regarding the theme of tolerance. This concern could be in the form of an explanation by the preacher when he said that he was understood to be not in accordance with the expectations of the congregation. As a result, the preacher prefers themes related to morals and faith.

Ustadz Abd Jalil, Imam of the Baiturrahim Mosque as the preacher said: "If I am a preacher, I choose a light theme. Not all people are able to properly digest every material presented. Not to mention the level of education of our people here is very different from the people in Java and Sulawesi, which have many Religious Education Institutions. "

Similar comments were made by Ustaz Sukri Nawir: "In choosing the sermon theme, I was more inclined to see the moment of time. So that I don't have too much trouble finding sermon material. For example, if the moment is the month of Shawwal, usually the theme related to the fasting of Shawwal that I take up. "

The issue of light theme choice as mentioned by Ustadz Abd. Jalil is one of the factors is the level of religious literacy of the people in Papua which is believed to be still low compared to other areas such as Java and Sulawesi. This is evidenced by the majority of $d a^{\prime} i$ are alumni from 
educational institutions outside Papua. Therefore, choosing a theme that is not heavy is an option to make the da'wah more easily accepted. In dakwah fiqh, the choice of options like this is part of the way of preaching with wisdom. Natsir said that wisdom is to know the dakwah ojek class in the sense of knowing the class understanding, the level of knowledge, and the character of the community whether it is hard or not hard. Each of them must be faced in an appropriate way of communication ${ }^{19}$.

In practice, the preachers also sometimes ignore the reference to the source of the sermon material. they are more likely to see the moment or when there is an event that is viral, usually used as the object of the sermon material. This content is then searched for theological arguments in the form of Qur'anic verses and Hadith as reinforcement of the sermon material. This proposition is often interpreted through the ability to think logically from the $d a^{\prime} i$ and then conveyed according to the rhetorical style of each preacher.

It is undeniable that the social conditions of Papua, especially Jayapura City, have greatly influenced social discourses, including religious discourses. If it is narrowed down narrowly, it also affects discourses on religious pulpits, especially religious lectures or sermons. In the religious context, it is stated that Islam is the second majority religion after Protestant Christianity. This majority religion has always been claimed to be the original religion of the Papuan people. Therefore, hegemony as an original religion certainly greatly influences the process of relations between religious communities, including in the dakwah patterns practiced by each religion. One example, for example, was when some priests questioned the existence of places of worship in government agencies such as the Religious Courts Office, public facilities such as Jayapura Harbor, or the issue of building a mosque on the Cenderawasih University Campus. Even the sound of the five call to prayer is sometimes seen as disturbing. Specifically related to da'wah activities, there were a number of priests who were suspicious of the activities of the Jamaah Tablig group in Entrop which were considered to be exclusive, so they questioned what they thought they were fighting for ${ }^{20}$.

One example of a text that is adaptive to social conditions in Jayapura is as follows by Suddin Lasahiya:

Ladies and gentlemen, Rahmatullah !! It is not easy to be istiqamah in today's world the temptation is greater, the lure of the world as if it is relentless, it is even considered that those who fight for the truth are considered to be disastrous, disturbing diversity, intolerance, radicalism and so on. This condition, the congregation, the Muslim congregation, I think we are back in the era of ignorance, when the prophet and his companions first preached the prophet, they were considered crazy when they invited them to the path of truth.

Suddin Lasahiya as preacher, is a former activist of Hizbut Tahrir Indonesia. If one looks at the sermon text he delivers, the nuances of the basis of mass organizations are listed in the sermon text. Such as "those who fight for the truth are considered to be disastrous, disturbing diversity, intolerance, radicalism and so on." In this text, it is indicated that mass organizations such as HTI and the like which always fight in the path of truth are considered as mass organizations to disturb diversity, intolerance and radicalism. However, however, in the next presentation, he only includes six messages that are quite 'light' about the theme discussed as follows:

The first is that we have faith in unifying our views, beliefs and speech in our daily life. Second, we maintain sincerity solely because of Allah SWT. Third, study and practice the entire Koran. The fourth is hanging out with pious people. The fifth is to

\footnotetext{
${ }^{19}$ Ramdani, Natsir, M: Fiqhi Dakwah, 1989.

${ }^{20}$ Ridwan, Insiden Tolikara Dan Jafar Umar Thalib: Kontroversi Mushalla Yang Dibakar Dan Drama Jihad Di Papua.
} 
study and unify the story of the nature of the previous pious people. and sixth, ask Allah SWT to keep giving istiqomah....

If digested deeper, the sermon texts are a safe-looking step, even though there is an implied message that there are mass organizations such as HTI and others that are accused of being intolerant and radical. However, he did not convey it in a vulgar manner as was the case with other HTI activists, remembering the strong rejection among the Jayapura community, both Muslims and other religions, against these mass organizations.

Furthermore, Muslims who are considered to be adherents of immigrant religion (not the religion of indigenous Papuans), in certain aspects of social relations must yield to local religions in order to create conditions of peace and harmony in religious life. This condition is quite influencing the discourse of the sermon in Jayapura. So that in choosing the theme of the sermon, the preachers tend to choose a theme that is safe and seems normative so that they do not fall into alleged provocations, including those from Muslims themselves or from other religions. As a result, the preacher on the pulpit tends to choose themes such as fiqh, good and bad morals, (worship), as well as matters of faith. They rarely mention the issue of religious tolerance. This is due to social psychological factors which want to avoid offense from other groups. At the same time, when discussing the issue of tolerance in religious pulpits, including Friday sermons, of course, one must use a sharp interpretation knife based on solid religious arguments. In this position, the preacher did not want to get caught up in controversy, so he chose a safer (safer) step.

In delivering sermons, preachers should also pay attention to aspects of cultural da'wah, namely by paying attention to local culture including local wisdom that develops in society such as local values or local expressions. One of the well-known local wisdoms, namely the slogan of a three stone furnace, should be explored by the preacher to gain sympathy from honey (the object of preaching). The use of local languages is no less important so that the content of the sermon is easier to understand and spreads in the listener's soul. This is in line with the word of Allah swt:

We did not send a messenger but in the language of his people, so that he could provide an explanation (Surah Ibrahim: 4). In another narration it is also mentioned:

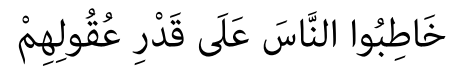

Talk (berkhutbahlah) with humans according to the level of ability to think.

The Qur'anic argument and the aforementioned history strongly recommend that in conveying da'wah content, it must pay attention to the local culture of the people who are the target of da'wah. Including in Jayapura City, the use of local wisdom content should not be ignored. However, the fact is that the majority of preachers / preachers in Jayapura City are preachers from ethnic groups outside Papua or can be referred to as ethnic immigrants such as from Java, Sulawesi, Maluku and so on. Therefore, the control of local Papuans is very minimal. From the information, several preachers stated that one of the reasons for the negligence of the preachers to include local kerifan in the content of their sermons was that their reading regarding this matter was still very minimal. So as previously stated, the preacher's content tends to be very flat and prioritizes Indonesian.

\section{E. Conclusion}

Friday sermons are one of the media for preaching. Therefore, reading the Friday Khutbah process is very important to see the trend of the da'wah theme map in Jayapura City. There are several things that are very important regarding the process of implementing the Friday Khutbah in Jayapura City: (1) The process of arranging Friday khatibs in Jayapura city is largely coordinated by the Jayapura City Ministry of Religion Office except in Heram and Muara Tami Districts as well as at several mosques outside these two districts. The procedure is that the Office of the Ministry of Religion writes to the mosque to include a list of preachers and is 
checked so that there is no clash of schedules for one particular preacher at a different mosque. A different procedure actually happened in Heram and Muaratami Districts. The process for determining Khatib Friday's is coordinated by the Musallah Mosque Communication Board (BKMM) in each district. The regulatory process also tends to be more than that carried out by the Office of the Ministry of Religion because the number of mosques that are coordinated is less, namely only 8 mosques in each district. (2) The Khutbah theme chosen by the preachers is generally about matters of faith, jurisprudence and morals. In addition, preachers in Jayapura City often see moments or events that are viral to be used as the theme of the sermon. It's just that the problem is that many Friday khatibs ignore themes related to local wisdom and hot local issues.

As an implication of the review of the Khutbah Jum'at content in Jayapura City, several recommendations as a follow-up as material for religious development are as follows: (1) The control measures undertaken by the Ministry of Religion over the implementation of the Friday Khutbah schedule in Jayapura City need to be increased by capturing all mosques. Meanwhile, in the case of Heram and Muara Tami Districts, the Jayapura City Ministry of Religion needs to carry out intense coordination regarding the $d a^{\prime} i s$ distribution and regeneration. (2) The Ministry of Religion needs to improve the quality of $d a^{\prime} i$ by providing education and training so that they are able to produce moderate, tolerant and sensitive $d a^{\prime} i$ to local culture. (3) There is a need for mapping related to the distribution of preachers, da'wah themes, the religious characteristics of community groups as objects of preaching so that the preaching delivered does not impress provocative da'wah just because it differs from diversity.

\section{References}

Abdillah, R. Pesan Dakwah Khatib Jum'at (Studi Kualitatif fi Masjid Nurul Fattah Jl. Demak Kecamatan Krembangan Surabaya Edisi Mei 2014 Minggu Ke-5 oleh Ust. Umar Haqqi AR). Universitas Islam Negeri Sunan Ampel Surabaya, 2015.

Abdillah, R. Pesan Dakwah Khatib Jum'at (Studi Kualitatif Di Masjid Nurul Fattah Jl. Demak Kecamatan Krembangan Surabaya Edisi Mei 2014 Minggu Ke-5 Oleh Ust. Umar Haqqi AR)., 2015.

Al-Zuhaili, W. Al-Fiqh Al-Islami Wa Adillatuh. Jilid II., 1985.

Kementerian Agama, RI. Moderasi Beragama, 2019. Kementerian Agama RI.

Khatmi, H. Tata Cara Khutbah Dan Kompetensi Khatib Jum'at Di Palangkaraya. Insitut Agama Islam Negeri Palangkaraya, 2016.

Kurniawati, T. "Naskah Khutbah Karya Uci Sanusi; Sebuah Edisi Teks Dan Kajian Topik." Jurnal Jaladri 3, no. 1 (2017): 43-50.

Masyhar, Ali, and F. S Harmoko. "Peran Khutbah Jum'at Dalam Mengantisipasi Radikalisme Beragama." Jurnal Pengabdian Hukum Indonesia 2, no. 5 (2019): 178-183.

Nasution, H. Islam Ditanjau Dari Berbagai Aspeknya. I. Universitas Indonesia Press, 1985.

Ramdani. Natsir, M: Fiqhi Dakwah, 1989.

Ridwan. Insiden Tolikara Dan Jafar Umar Thalib: Kontroversi Mushalla Yang Dibakar Dan Drama Jihad Di Papua. Kementerian Agama Provinsi Papua, 2017.

Shihab, M. Quraish. Wasathiyyah: Wawasan Islam Tentang Moderasi Beragama. Tangerang: Lentera Hati, 2019.

Singh, B. dan A. M. M. Jejaring Radikalisme Islam Di Indonesia. Kencana, 2012.

Syalabi, A. Sejarah Dan Kebudayaan Islam. II. Al Husna Zikra, 2000.

Syamsurijal. Pergeseran Paham Keagamaan Mahasiswa Islam Di Kawasan Timur Indonesia, 2015. 
Titscher, Stefan, E. al. Methods of Text and Discourse Analysis. Metode Analisis Teks Dan Wacana. Pustaka, 2009.

Wibowo, I. S. W. Aplikasi Praktis Bagi Penelitian Dan Skripsi Komunikasi. Mitra Wacana Media, 2013.

\section{Acknowledgment}

Thank you to all parties who helped carry out this research from beginning to end. Deep thanks to Saprillah, as the Head of the Makassar Research and Development Center for Religion, who assigned researchers so that the research can be carried out. Likewise, thanks to Ust. Burhanuddin (Islamic Religion Counselor, Jayapura City Ministry of Religion Office), Ustadz Muh. Taslim, Ustadz Eko Siswanto, Ustadz Sukman, Ustadz Abdul Jalil, Ustadz Sukri Nawir, and Ustadz Suddin Lasahiya for the information provided to make it easier for researchers to collect research data. 